\title{
(6) OPEN ACCESS \\ Ranibizumab in retinal vein occlusion: treatment recommendations by an expert panel
}

\author{
Heinrich Gerding, ${ }^{1,2}$ Jordi Monés, ${ }^{3}$ Ramin Tadayoni, ${ }^{4}$ Francesco Boscia, ${ }^{5}$ Ian Pearce, ${ }^{6}$ \\ Siegfried Priglinger ${ }^{7}$
}

${ }^{1}$ Augenzentrum Klinik Pallas, Olten, Switzerland

${ }^{2}$ Department of

Ophthalmology, University of Muenster, Muenster, Germany ${ }^{3}$ Institut de la Màcula i de la Retina, Centro Médico Teknon and Barcelona Macula

Foundation, Barcelona, Spain

${ }^{4}$ Department of

Ophthalmology, Hôpital

Lariboisière, Université Paris

Diderot-Sorbonne Paris Cité,

AP-HP, Paris, France

${ }^{5}$ Department of

Ophthalmology, University of

Sassari, Sassari, Italy

${ }^{6}$ St Paul's Eye Unit, Royal

Liverpool \& Broadgreen

University Hospitals NHS Trust,

Liverpool, UK

${ }^{7}$ Department of

Ophthalmology, General

Hospital (AKH), Linz, Austria

Correspondence to

Professor Heinrich Gerding,

Augenzentrum Klinik Pallas,

Louis Giroud-Strasse 20,

CH-4600 Olten, Switzerland:

heinrich.gerding@klinik-pallas.ch

Received 3 February 2014

Revised 30 May 2014

Accepted 3 June 2014

Published Online First

29 July 2014

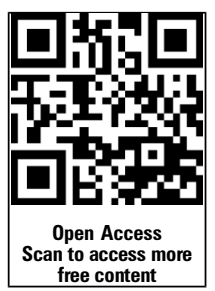

CrossMark

To cite: Gerding $H_{\text {, }}$

Monés J, Tadayoni $\mathrm{R}$, et al.

Br J Ophthalmol

2015:99:297-304.

\section{ABSTRACT}

Retinal vein occlusion (RVO) is a common cause of retinal vascular disease, resulting in potentially irreversible loss of vision despite the existence of several therapeutic options. The humanised monoclonal antibody fragment ranibizumab binds to and inhibits vascular endothelial growth factor, a key driver of macular oedema in RVO. In 2010, ranibizumab was approved in the USA for the treatment of macular oedema in RVO and, in 2011, ranibizumab was approved in the European Union for the treatment of visual impairment caused by macular oedema secondary to RVO in branch and central RVO. Ranibizumab provides an additional therapeutic option for this complex disease: an option that was not fully considered during the preparation of current international guidelines. An expert panel was convened to critically evaluate the evidence for treatment with ranibizumab in patients with visual impairment caused by macular oedema secondary to RVO and to develop treatment recommendations, with the aim of assisting physicians to optimise patient treatment.

\section{INTRODUCTION}

\section{Background}

Retinal vein occlusion (RVO), the second most common cause of retinal vascular disease after diabetic retinopathy, is a frequent cause of vision loss. ${ }^{1-4}$ According to National Eye Institute Visual Function Questionnaire (NEI VFQ)-25 scores, RVO significantly impacts vision-related quality of life (QoL) compared with individuals with no ocular disease. $^{56}$

Until recently, the standard of care for macular oedema resulting from branch RVO (BRVO) was macular grid laser photocoagulation, based on outcomes of the Branch Vein Occlusion Study, which showed a mean 3-year improvement of 1.33 lines of vision in treated patients $(n=43)$ versus 0.23 lines in untreated controls $(n=35 ; p<0.0001) .{ }^{1}$

Although macular laser treatment reduced macular oedema in individuals with central RVO (CRVO), the Central Retinal Vein Occlusion Study did not show any significant visual acuity (VA) benefit. $^{7}$ Intraocular corticosteroids have provided similar benefits to macular grid laser photocoagulation in BRVO and superior visual outcomes compared with observation in CRVO; however, these corticosteroids are associated with elevated intraocular pressure and cataract development. ${ }^{8} 9$ In the GENEVA study, an intravitreal dexamethasone implant provided improvements in mean bestcorrected VA (BCVA) for patients with BRVO and
CRVO, but was also associated with elevated intraocular pressure and cataract. ${ }^{10}$

In 2010, ranibizumab was approved in the USA for the treatment of macular oedema after $\mathrm{RVO}^{11}$ and was approved in 2011 in the European Union (EU) for the treatment of visual impairment due to macular oedema secondary to BRVO and CRVO. ${ }^{12-14}$ Current international guidelines were prepared before approval was granted; ${ }^{15-17}$ therefore, clinical guidance on how ranibizumab can best be incorporated into clinical practice is warranted. This expert panel's recommendations are to help guide the use of ranibizumab in RVO.

\section{Antivascular endothelial growth factor agents in RVO}

In RVO, functional and structural changes in the retina, including reduced blood flow in the retinal capillaries, lead to hypoxia which, in turn, leads to upregulation of vascular endothelial growth factor (VEGF). ${ }^{18} 19$ VEGF disrupts the blood-retinal barrier, stimulates vascular endothelial growth and increases vascular permeability. ${ }^{19}$ Elevated VEGF concentrations have been detected in the ocular fluid of patients with BRVO and CRVO and correlate with the severity of macular oedema. ${ }^{20-24}$

Anti-VEGF therapies have been approved for ocular use for 10 years, initially for treatment of neovascular AMD (nAMD). ${ }^{25}$ Ranibizumab has been approved for treatment of diabetic macular oedema and macular oedema following RVO and choroidal neovascularisation in pathological myopia, ${ }^{12} 26$ and aflibercept has been licensed for the treatment of nAMD and CRVO. ${ }^{25}{ }^{27}$ Bevacizumab, despite not being licenced for use in ophthalmic indications, and ranibizumab, are the two most commonly used anti-VEGF drugs in ophthalmic patients, although aflibercept has shown rapid uptake. ${ }^{25}$

Bevacizumab has been compared with ranibizumab for the treatment of nAMD in several randomised clinical trials. ${ }^{28-31}$ These studies demonstrated equivalence of bevacizumab and ranibizumab in terms of clinical efficacy. However, they were not powered to compare safety, and questions on this matter are still outstanding, although no significant differences were found concerning arteriothrombotic events.

Several anti-VEGF agents have been evaluated for the treatment of RVO, including ranibizumab, bevacizumab, pegaptanib and aflibercept. Case series have indicated that treatment with bevacizumab can benefit patients with RVO, ${ }^{32-36}$ although bevacizumab is not licensed for intraocular use, and the optimal dosing schedule, long-term outcomes 
and risks of adverse events (AE) for patients with RVO remain unclear. A retrospective study of 81 patients compared the efficacy of ranibizumab to bevacizumab for the treatment of macular oedema secondary to RVO and observed that both were effective with no significant difference in change in BCVA. ${ }^{37}$ Ranibizumab has not been compared with pegaptanib or aflibercept in this indication.

Studies to investigate the use of anti-VEGF agents for the treatment of RVO are ongoing; for example, the Study of Comparative Treatments for RVO (SCORE2) is a multicentre, prospective, randomised, non-inferiority trial for macular oedema secondary to CRVO, comparing bevacizumab with aflibercept. ${ }^{38}$ At the time of writing, this trial was not yet open for enrolment; the estimated completion date is March 2018.

Available data show that patients with RVO achieved improvements in VA after treatment with pegaptanib or aflibercept compared with sham injections. ${ }^{39}{ }^{40}$ Pegaptanib was assessed in a phase II study of 65 patients, although this was only over 30 weeks and the long-term response remains unclear. ${ }^{39}$ The phase III COPERNICUS trial investigated aflibercept treatment for macular oedema secondary to CRVO in 114 patients. ${ }^{40}$ The results of this study demonstrated that the proportion of patients gaining $\geq 15$ letters in BCVA from baseline at weeks 24 , 52 and 100 was significantly greater for patients receiving aflibercept compared with sham injection $(\mathrm{p}<0.001)$. The most frequent ocular serious $\mathrm{AE}$ from baseline to 100 weeks was vitreous haemorrhage $\left(0.9 \%\right.$ vs $6.8 \%$ with sham injection). ${ }^{40}$

Therefore, anti-VEGF therapy is a generally well-accepted approach to the treatment of RVO, and there is no evidence to suggest either the superiority of, or preference for, any of the currently available agents. As such, the use of ranibizumab and alternative anti-VEGF agents differs considerably between countries.

\section{Development of recommendations for ranibizumab in patients with RVO}

An independent European expert panel was convened to discuss the available evidence from clinical studies of ranibizumab in patients with RVO.

Recommendations were based on evidence from prospective, randomised controlled trials (see online supplementary material). For clinical scenarios for which robust clinical evidence was limited, small single-centre studies or case series were also considered, with appropriate reservations. The panel sought the advice of an expanded committee of 43 European ophthalmologists for specific clinical questions when available evidence was limited.

\section{RANIBIZUMAB IN RVO: SUMMARY OF EVIDENCE}

The BRAVO (BRAnch Retinal Vein Occlusion) and CRUISE (Central Retinal Vein OcclUsIon) studies were pivotal phase III trials for the approval of ranibizumab for the treatment of visual impairment due to macular oedema secondary to RVO. ${ }^{12} 4142$ Patients with macular oedema secondary to BRVO or CRVO were randomised 1:1:1 to receive six monthly intravitreal injections of ranibizumab $0.3 \mathrm{mg}$, ranibizumab $0.5 \mathrm{mg}$ or sham, followed by a 6-month, as-needed (PRN) phase, during which all patients were eligible for ranibizumab treatment. In the BRAVO study, rescue grid macular laser photocoagulation was permitted from month $3 .{ }^{41}$ In these studies, ranibizumab treatment was associated with significant improvements in BCVA, observed from day 7, with BCVA gains sustained over 12 months of treatment. ${ }^{4344}$
Visual outcomes in the BRAVO study

In the BRAVO study, the mean change in BCVA from baseline at month 6 was +18.3 letters in the ranibizumab $0.5 \mathrm{mg}$ group $(n=131)$ compared with +7.3 letters with sham $(n=132$; $\mathrm{p}<0.0001) .{ }^{41}{ }^{43}$ Overall, $61.1 \%$ of patients treated with ranibizumab $0.5 \mathrm{mg}$ and $28.8 \%$ of patients who received sham gained $\geq 15$ letters at month $6(\mathrm{p}<0.0001){ }^{41}$ At month 12 , mean BCVA improvements were +18.3 letters for ranibizumab $0.5 \mathrm{mg}$ versus +12.1 letters with delayed treatment $(p<0.01$; figure $1 \mathrm{~A}) .{ }^{43}$ The proportion of patients gaining $\geq 15$ letters with ranibizumab $0.5 \mathrm{mg}$ at month $12(60.3 \%)$ was similar to that at month $6(61.1 \%)$, but this increased from $28.8 \%$ to $43.9 \%$ for the delayed treatment group. ${ }^{41} 43$

\section{Visual outcomes in the CRUISE study}

In the CRUISE study, 6-month BCVA outcomes showed significant improvements of +14.9 letters in the ranibizumab $0.5 \mathrm{mg}$ group $(\mathrm{n}=130)$ compared with +0.8 letters in the sham group $(\mathrm{n}=130 ; \mathrm{p}<0.0001) .{ }^{42}{ }^{44}$ BCVA improvements with ranibizumab $0.5 \mathrm{mg}$ were sustained to month 12 and were significantly greater than those for the delayed treatment group $(+13.9$ letters vs +7.3 letters, respectively; $\mathrm{p}<0.001$; figure $1 \mathrm{~B}$ ). ${ }^{44}$ At month 6, the proportion of patients who gained $\geq 15$ letters with ranibizumab $0.5 \mathrm{mg}$ was significantly greater compared with sham $(47.7 \%$ vs $16.9 \%$, respectively; $\mathrm{p}<0.0001),{ }^{42}$ and was also greater in the delayed treatment group at month $12(50.8 \%$ vs $33.1 \%$, respectively). ${ }^{44}$

\section{Anatomical outcomes in the BRAVO and CRUISE studies}

The BRAVO and CRUISE studies demonstrated that ranibizumab was associated with significantly greater mean reductions in central foveal thickness (CFT). At month 6 of the BRAVO study, the mean CFT reduction was $-345.2 \mu \mathrm{m}$ with ranibizumab $0.5 \mathrm{mg}$ and $-157.7 \mu \mathrm{m}$ with sham $(\mathrm{p}<0.0001) .{ }^{41}$ This reduction was sustained to month 12 with ranibizumab $0.5 \mathrm{mg}(-347.4 \mu \mathrm{m})$ compared with a reduction of $-273.7 \mu \mathrm{m}$ in the delayed treatment group $(\mathrm{p}<0.05) .{ }^{43}$

Similarly, at month 6 of the CRUISE study, mean reductions in CFT of $-452.3 \mu \mathrm{m}$ and $-167.7 \mu \mathrm{m}$ were observed with ranibizumab $0.5 \mathrm{mg}$ and sham, respectively $(\mathrm{p}<0.0001){ }^{42}$ At month 12 , the mean CFT reduction was $-462.1 \mu \mathrm{m}$ with ranibizumab $0.5 \mathrm{mg}$ compared with $-427.2 \mu \mathrm{m}$ with delayed treatment. $^{44}$

\section{Safety outcomes in the BRAVO and CRUISE studies}

Ranibizumab was generally well tolerated, with no new safety risks identified up to month 12 . In the BRAVO study, cataract was reported in $6.2 \%$ of the ranibizumab $0.5 \mathrm{mg}$ group, $3.1 \%$ of the sham group up to month 6 , and $2.6 \%$ from months 6 to 12 after patients switched to ranibizumab $0.5 \mathrm{mg}$. One incidence of endophthalmitis in the ranibizumab $0.5 \mathrm{mg}$ group was reported. Six serious AEs (SAE) potentially related to VEGF inhibition were reported with ranibizumab $0.5 \mathrm{mg}$ : one each of haemorrhagic stroke, acute myocardial infarction, unstable angina, hypertension, non-ocular haemorrhage and intestinal perforation. In the delayed treatment group, one SAE of haemorrhagic stroke was reported up to month 6 and one SAE each of acute myocardial infarction and hypertension was reported during months $6-12 .{ }^{43}$

In the CRUISE study, cataract was reported in $7.0 \%$ of patients treated with ranibizumab $0.5 \mathrm{mg}, 1.8 \%$ in the delayed treatment group, and $0 \%$ in the sham group. Endophthalmitis was not reported for any treatment group. Four SAEs possibly 
$A \neg-$ Sham/0.5 mg (n=132) $\triangle \triangle \backsim-$ Ranibizumab $0.3 \mathrm{mg}(\mathrm{n}=134) \leadsto \sim$ Ranibizumab $0.5 \mathrm{mg}(\mathrm{n}=131)$

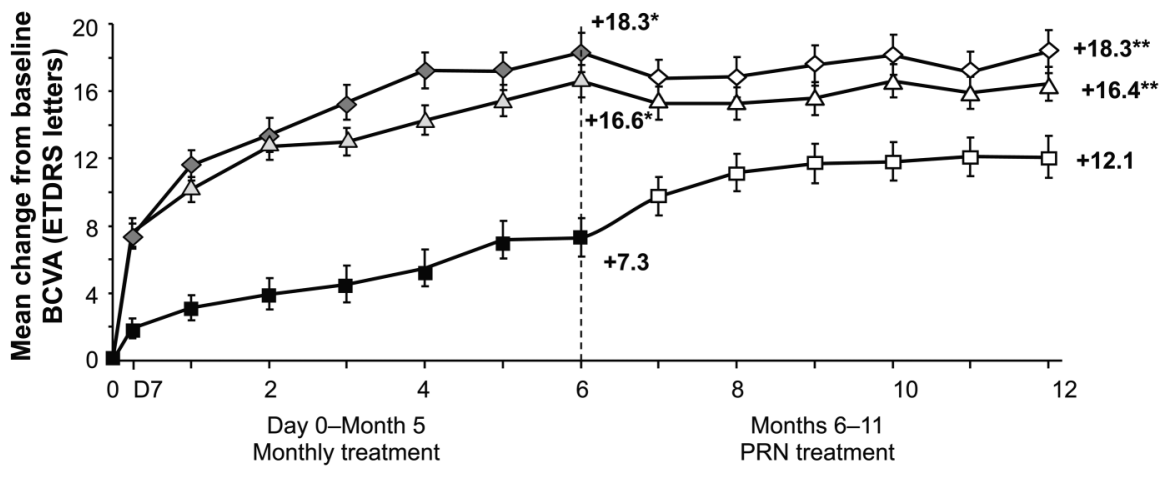

Month

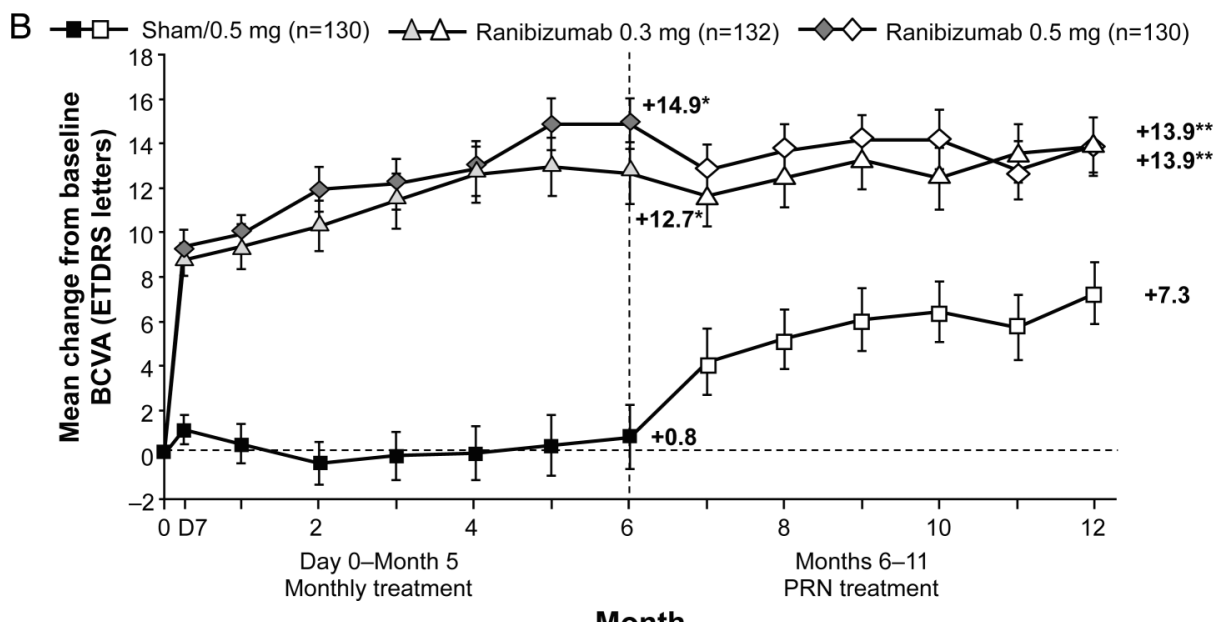

Month

Figure 1 The (A) BRAVO and (B) CRUISE studies: mean change in baseline BCVA letter score in study eye over time to month 12 after treatment with ranibizumab $0.3 \mathrm{mg}, 0.5 \mathrm{mg}$ or sham. ${ }^{43} 44$ In both studies, visual gains during treatment were generally maintained in the ranibizumab treatment groups during the observation periods. There were substantial improvements in visual acuity in the sham/ranibizumab $0.5 \mathrm{mg}$ groups during observation; however, in the BRAVO and CRUISE studies the mean change from baseline BCVA score of the sham/ranibizumab $0.5 \mathrm{mg}$ groups remained significantly different from those of the ranibizumab $0.3 \mathrm{mg}$ and $0.5 \mathrm{mg}$ groups at month 12 . In both studies, the earliest statistically significant group difference was at day 7. The last-observation carried forward method was used to impute missing values. Vertical bars are \pm 1 SE of the mean. ${ }^{*} p<0.0001$ vs sham; ${ }^{*} p<0.01$ vs sham/ranibizumab $0.5 \mathrm{mg} ; t p<0.0001$ vs sham, $\uparrow+p<0.001$ vs sham/ranibizumab $0.5 \mathrm{mg}$. BCVA, best-corrected visual acuity; ETDRS, Early Treatment Diabetic Retinopathy Study; PRN, as needed.

related to VEGF inhibition were reported in the $0.5 \mathrm{mg}$ group (ischaemic stroke, transient ischaemic attack, myocardial infarction and angina pectoris). In the delayed treatment group, there were two SAEs (myocardial infarction and hypertension) up to month 6 , but none reported during months $6-12 .{ }^{44}$

\section{The HORIZON study}

Patients completing the BRAVO and CRUISE trials were eligible for the open-label HORIZON cohort 2 study. ${ }^{45}$ One-year results (corresponding to 2 years of treatment) suggest that PRN ranibizumab dosing was adequate to maintain visual gains in patients with BRVO. Net gains of 17.5 letters and 15.6 letters from BRAVO baseline were observed for patients initially randomised to ranibizumab $0.5 \mathrm{mg}(n=104)$ and sham $(n=97)$, respectively. Although some loss of efficacy was observed in patients with CRVO, there was an overall improvement of 12.0 letters and 7.6 letters, respectively, from the CRUISE baseline for patients initially randomised to ranibizumab $0.5 \mathrm{mg}$ $(n=99)$ and sham $(n=98)$. Of note, the negative impact of delayed treatment was reduced in BRVO patients over the 12-month period, possibly because of the availability of rescue laser photocoagulation from month 3 in the BRAVO study. During the entire 24-month study period, increased intraocular pressure was reported for two patients with BRVO and one patient with CRVO. There were no cases of traumatic cataract (lens damage). Two patients with CRVO experienced endophthalmitis.

\section{The retinal vein occlusion (ROCC) study}

This 6-month, prospective randomised trial compared the efficacy and safety of ranibizumab $(n=15)$ with sham $(n=14)$ in patients with CRVO. ${ }^{46}$ Patients received three consecutive monthly injections of ranibizumab $0.5 \mathrm{mg}$ or sham: subsequent treatment was administered if macular oedema in the central macular area persisted. At month 6 , a mean number of 4.3 ranibizumab injections was associated with a BCVA mean improvement of 12 letters $(p=0.040)$ compared with a loss of 1 letter with sham treatment $(p=0.765)$. The mean CFT reduction at month 6 was $-304 \mu \mathrm{m}$ with ranibizumab $(\mathrm{p}<0.001)$ and $-151 \mu \mathrm{m}$ in the sham group $(\mathrm{p}=0.017)$, with significantly greater improvements with ranibizumab versus sham $(p=0.05)$. 
Table 1 Published studies providing primary data on ranibizumab in patients with visual impairment or macular oedema secondary to $\mathrm{RVO}^{47-53}$

\begin{tabular}{|c|c|c|c|c|}
\hline Reference & Risard et $a l^{47}$ & Campochiaro et $a l^{48}$ & Spaide $e t$ al ${ }^{49}$ & Campochiaro et $a l^{50}$ \\
\hline Study design & Prospective, open label & $\begin{array}{l}\text { Prospective, randomised, } \\
\text { masked trial }\end{array}$ & $\begin{array}{l}\text { Randomised, open } \\
\text { label }\end{array}$ & Randomised, uncontrolled \\
\hline Duration (months) & $\begin{array}{l}36 \\
24 \text {-month data available }\end{array}$ & 24 & 12 & 6 \\
\hline Population & Perfused CRVO & BRVO/CRVO & CRVO & BRVO/CRVO \\
\hline Number of patients & 20 & 40 (BRVO, $n=20 ;$ CRVO, $n=20$ ) & 20 & $\begin{array}{l}40 \text { (BRVO, } \mathrm{n}=20 ; \text {; CRVO, } \\
\mathrm{n}=20 \text { ) }\end{array}$ \\
\hline Ranibizumab treatment & $\begin{array}{l}\text { Cohort } 1: 0.3 \mathrm{mg}(\mathrm{n}=5) \text { or } 0.5 \mathrm{mg} \\
(\mathrm{n}=5) \text {; } \\
3 \times \text { monthly then PRN ( } \mathrm{q} 3 \mathrm{~m} \text { monitoring } \\
\text { amended } \\
\text { to monthly in year } 2) \text {; } \\
\text { Cohort } 2: 0.3 \mathrm{mg}(\mathrm{n}=5) \text { or } 0.5 \mathrm{mg} \\
(\mathrm{n}=5) \text {; } \\
3 \times \text { monthly then PRN ( } \mathrm{q} 1 \mathrm{~m} \\
\text { monitoring) }\end{array}$ & $\begin{array}{l}0.3 \mathrm{mg} \text { or } 0.5 \mathrm{mg} \text { at } \mathrm{BL} \text { and months } 1 \text { and } 2 \text { then } \\
\text { PRN after month } 12\end{array}$ & $\begin{array}{l}0.5 \mathrm{mg} \text { at } \mathrm{BL} \text { and } \\
\text { months } 1 \text { and } 2 \text {, } \\
\text { then PRN }\end{array}$ & $\begin{array}{l}3 \times \text { monthly } 0.3 \mathrm{mg} \text { or } \\
0.5 \mathrm{mg}\end{array}$ \\
\hline $\begin{array}{l}\text { Mean number of } \\
\text { ranibizumab injections }\end{array}$ & NR & 2 (BRVO); 3.5 (CRVO) & 8.5 & NR \\
\hline $\begin{array}{l}\text { Mean BCVA change at } \\
\text { month } 6 \text { (letters) }\end{array}$ & NR & $\begin{array}{l}0.3 \mathrm{mg} \text { and } 0.5 \mathrm{mg} \text { (pooled):* } \\
+16.1 \text { (BRVO); }+12.0 \text { (CRVO) }\end{array}$ & $\begin{array}{l}0.5 \mathrm{mg}:+10.4 \\
(p=0.001)^{*}\end{array}$ & $\begin{array}{l}0.3 \mathrm{mg}:+11 \text { (CRVO) } \dagger \\
0.5 \mathrm{mg}:+3 \text { (CRVO)† } \\
0.3 \mathrm{mg}:+15 \text { (BRVO) } \dagger \\
0.5 \mathrm{mg}:+14.5 \text { (BRVO) } \dagger\end{array}$ \\
\hline $\begin{array}{l}\text { Mean BCVA change at } \\
\text { month } 12 \text { (letters) }\end{array}$ & $\begin{array}{l}\text { Cohort 1: }+10.0 \\
\text { Cohort 2: }+3.7\end{array}$ & $\begin{array}{l}0.3 \mathrm{mg} \text { and } 0.5 \mathrm{mg} \text { (pooled): } \\
+17.8 \text { (BRVO); }+8.5 \text { (CRVO) }\end{array}$ & $0.5 \mathrm{mg}:+18.5$ & NR \\
\hline $\begin{array}{l}\text { Patients gaining } \geq 15 \text { letters at } \\
\text { month } 12(\%)\end{array}$ & $\begin{array}{l}\text { Cohort 1: } 30 \\
\text { Cohort 2: } 30\end{array}$ & $\begin{array}{l}0.3 \mathrm{mg} \text { and } 0.5 \mathrm{mg} \text { (pooled):‡ } \\
59 \text { (BRVO); } 28.6 \text { (CRVO) }\end{array}$ & $0.5 \mathrm{mg}: 56.3$ & $\begin{array}{l}0.3 \mathrm{mg} \text { pooled: } 70 \\
0.5 \mathrm{mg} \text { pooled: } 40\end{array}$ \\
\hline OCT change at month 6 & NR & $\begin{array}{l}0.3 \mathrm{mg} \text { and } 0.5 \mathrm{mg} \text { (pooled) CFT:* } \\
-264.4 \mu \mathrm{m} \text { (BRVO); } \\
-260.5 \mu \mathrm{m} \text { (CRVO) }\end{array}$ & $\begin{array}{l}0.5 \mathrm{mg}:-317 \mu \mathrm{m} \\
\text { CMT }\end{array}$ & $\begin{array}{l}0.3 \mathrm{mg}:-220 \mu \mathrm{m} \text { (CRVO) } \\
0.5 \mathrm{mg}:-86 \mu \mathrm{m} \text { (CRVO) } \\
0.3 \mathrm{mg}:-213.5 \mu \mathrm{m} \\
\text { (BRVO) } \\
0.5 \mathrm{mg}:-214.5 \mu \mathrm{m} \\
\text { (BRVO) }\end{array}$ \\
\hline OCT change at month 12 & $\begin{array}{l}\text { Cohort 1: }-304 \mu \mathrm{m} \mathrm{CRT}^{*} \\
\text { Cohort 2: }-282 \mu \mathrm{m} \mathrm{CRT}^{*}\end{array}$ & $\begin{array}{l}0.3 \mathrm{mg} \text { and } 0.5 \mathrm{mg} \text { (pooled) CFT: } \\
-229.5 \mu \mathrm{m} \text { (BRVO); } \\
-129 \mu \mathrm{m} \text { (CRVO) }\end{array}$ & $\begin{array}{l}0.5 \mathrm{mg}: \\
-389 \mu \mathrm{m} \text { CFT }\end{array}$ & NR \\
\hline Incidence of ocular AEs (n) & $\begin{array}{l}1 \text { increased oedema/ischaemia } \\
1 \text { myocardial infarction } \\
1 \text { cerebrovascular accident }\end{array}$ & NR & NR & 0 treatment-related AEs \\
\hline
\end{tabular}

\begin{tabular}{|c|c|c|c|}
\hline Reference & Alfaro et $a l^{52}$ & Pieramici et $a l^{53}$ & Wykrota et $a l^{54}$ \\
\hline Study design & Non-randomised, open label & Randomised, open label & Non-randomised, interventional case series \\
\hline Duration (months) & 12 & 24 & 6 \\
\hline Population & BRVO & CRVO & BRVO/CRVO \\
\hline Number of patients & $20 \S$ & 10 & 16 (BRVO, $\mathrm{n}=11 ;$ CRVO, $\mathrm{n}=5$ ) \\
\hline Ranibizumab treatment & $\begin{array}{l}0.3 \mathrm{mg} \text { or } 0.5 \mathrm{mg} \text { at } \mathrm{BL} \text { and months } \\
1 \text { and } 2 \text {, then PRN }\end{array}$ & $\begin{array}{l}0.3 \mathrm{mg} \text { or } 0.5 \mathrm{mg} \text { at } \mathrm{BL} \text { and months } 1 \text { and } \\
2 \text {, then PRN }\end{array}$ & $0.5 \mathrm{mg}^{* *}$ \\
\hline $\begin{array}{l}\text { Mean number of } \\
\text { ranibizumab injections }\end{array}$ & 7 & 4.5 & 3.2 \\
\hline $\begin{array}{l}\text { Mean BCVA change at month } 6 \text { (letters or } \\
\text { Snellen equivalent) }\end{array}$ & $0.3 \mathrm{mg}$ and $0.5 \mathrm{mg}$ (pooled): +15.5 & $\begin{array}{l}0.3 \mathrm{mg}:+8.0 \\
0.5 \mathrm{mg}: 3\end{array}$ & $\begin{array}{l}0.5 \mathrm{mg}: 20 / 400 \text { at } B L \text { to } 20 / 100 \text { at month } 6 \\
\text { ( } p=0.01 \text { at month } 6 \\
\text { compared with } B L \text { ) }\end{array}$ \\
\hline $\begin{array}{l}\text { Mean BCVA change at } \\
\text { month } 12 \text { (letters) }\end{array}$ & $0.3 \mathrm{mg}$ and $0.5 \mathrm{mg}$ (pooled): +16.2 & $\begin{array}{l}0.3 \mathrm{mg} \text { and } 0.5 \mathrm{mg} \text { (pooled): }+19 \\
(p=0.859)\end{array}$ & NR \\
\hline Patients gaining $\geq 15$ letters at month $12(\%)$ & $0.3 \mathrm{mg}$ and $0.5 \mathrm{mg}$ (pooled): 55 & $\begin{array}{l}0.3 \mathrm{mg}: 201 \\
0.5 \mathrm{mg}: 409\end{array}$ & NR \\
\hline OCT change at month 6 & $\begin{array}{l}0.3 \mathrm{mg} \text { and } 0.5 \mathrm{mg} \text { (pooled): - } \\
164.4 \mu \mathrm{m} \text { CRT }\end{array}$ & $\begin{array}{l}0.3 \mathrm{mg} \text { and } 0.5 \mathrm{mg} \text { (pooled): }-88 \mu \mathrm{m} \text { CRT } \\
(p=0.154)\end{array}$ & $0.5 \mathrm{mg}:-366 \mu \mathrm{m}$ CRT \\
\hline OCT change at month 12 & $\begin{array}{l}0.3 \mathrm{mg} \text { and } 0.5 \mathrm{mg} \text { (pooled): - } \\
167.9 \mu \mathrm{m} \text { CRT }\end{array}$ & NR & NR \\
\hline Incidence of ocular AEs (n) & $0.3 \mathrm{mg}$ and $0.5 \mathrm{mg}$ (pooled): 0 SAEs & $0.3 \mathrm{mg}$ and $0.5 \mathrm{mg}$ (pooled): 0 SAEs & $0.5 \mathrm{mg}: 0$ \\
\hline
\end{tabular}

\footnotetext{
*3-month data provided.

tMedian values reported.

\$24-month data provided for 17 patients with BRVO and 14 patients with CRVO.

$\S$ Expected enrolment, data available for 11 patients.

19-month data provided.

**Dosing regimen not provided.

$A E$, adverse event; $B C V A$, best-corrected visual acuity; $B L$, baseline; BRVO, branch retinal vein occlusion; CFT, central foveal thickness; CMT, central macular thickness; CRT, central retinal thickness; CRVO, central retinal vein occlusion; NR, not reported; OCT, optical coherence tomography; PRN, as needed; q1 m, every month; q3 m, every 3 months; RVO, retinal vein occlusion; SAE, serious adverse event.
} 
Eligibility for ranibizumab treatment

- Ranibizumab is indicated for the treatment of visual impairment due to macular oedema secondary to BRVO or CRVO. For hemiretinal RVO, a treatment approach similar to that for BRVO is suggested.

- When treating newly diagnosed RVO, physicians should be aware of common risk factors, to follow good clinical practice and refer patients to the appropriate specialist if necessary.

- Physicians should be vigilant for signs of rubeosis during follow-up of all RVO cases, particularly CRVO. The role of ranibizumab in the prevention and management of rubeosis is still unclear and requires further study.

- Ranibizumab is generally not recommended for patients presenting with irreversible ischaemic visual loss because of the limited availability of phase III trial data in this patient population. However, ranibizumab treatment may be considered when macular oedema is present in the perfused retinal areas adjacent to the macular ischaemic retinal zones, because some patients may experience a benefit.

Commencement of ranibizumab treatment

- Early treatment is recommended to optimise long-term VA benefits.

- There are different approaches regarding when to commence treatment, ranging from immediate treatment to treatment after 13 months of observation.

- Evidence suggests that delaying ranibizumab treatment results in slower overall anatomical improvements and lower net improvements in BCVA and vision-related QoL.

Initiation of ranibizumab treatment

- In accordance with the approved label, ranibizumab treatment should be initiated with monthly injections and continued until the patient's VA is stable for three consecutive monthly assessments performed while on treatment.

- OCT permits detailed assessment and quantification of the degree and type of oedema and, as such, is considered essential for determining whether visual impairment in patients with RVO is caused by macular oedema.

- If patients do not experience any improvement in BCVA for the initial three monthly assessments while on treatment, continued treatment is not recommended.

Treatment interruption

- The attainment of stable VA for 3 consecutive months while on treatment (at least three injections when ranibizumab is initiated and a minimum of two injections if treatment is restarted) is considered sufficient for temporary interruption of treatment. Patients should continue to undergo monthly monitoring for VA.

Follow-up examinations to determine retreatment need

- Monthly ranibizumab treatment is reinitiated when a loss of VA resulting from macular oedema secondary to RVO is observed.

- No threshold for VA loss to trigger retreatment has been defined.

- OCT should be performed to determine the extent of macular oedema; if VA has not changed but OCT clearly shows worsening, treatment may be considered on an individual basis (eg, according to previous history of dynamics of the VA related to OCT).

- Formal assessments of QoL may be impractical in daily practice. However, the patient's perception of the benefits of the chosen treatment should be considered.

Additional laser treatment

- There is no evidence that combining grid macular laser photocoagulation with ranibizumab treatment provides additional clinical benefit for patients with visual impairment resulting from macular oedema secondary to BRVO.

- Focal or panretinal laser photocoagulation in combination with anti-VEGF therapy is recommended by some physicians in the treatment of ischaemic retinal areas; the rationale for this approach is to decrease the amount of VEGF by reducing the ischaemic trigger.

- Although not proven, this approach seems logical, but randomised clinical trials will be required to verify this approach.

$B C V A$, best-corrected visual acuity; BRVO, branch retinal vein occlusion; CRVO, central retinal vein occlusion; OCT, optical coherence tomography; QoL, quality of life; RVO, retinal vein occlusion; VA, visual acuity; VEGF, vascular endothelial growth factor.

No cases of endophthalmitis, infection, retinal detachment or iatrogenic cataract formation were reported.

Additional studies, including prospective, open-label studies and randomised controlled trials, provide further evidence of the benefits of ranibizumab in the treatment of BRVO and CRVO (table 1). ${ }^{47-53}$ So far, no controlled study data are available on the impact of ranibizumab on intraretinal or cilioretinal shunt or collateral vessel formation in eyes with venous occlusion.

\section{RANIBIZUMAB IN RVO: TREATMENT RECOMMENDATIONS}

Recommendations for the use of ranibizumab in the treatment of RVO are summarised in the box 1 .

\section{Eligibility for ranibizumab treatment}

Visual impairment

Ranibizumab is indicated for the treatment of visual impairment due to macular oedema secondary to BRVO or CRVO. ${ }^{12}$ Reduced VA is a universally recognised indicator of visual impairment and the measure employed to indicate when ranibizumab treatment should commence. Although 20/40 has often been used as a threshold for VA impairment in clinical trials, many ophthalmologists would consider this too low. The physician's own judgement may better determine what VA loss or visual function loss is significant to the individual patient to commence treatment. There is no level of VA for which treatment is contraindicated as a rule; even patients with normal VA could present 
with significant impairment of contrast sensitivity or visual field. Therefore, although VA may be the leading indicator for treatment with ranibizumab in patients with RVO, other functional parameters may be useful on a patient-by-patient basis to fully determine the need for treatment.

\section{Hemiretinal vein occlusions}

There is currently no universally accepted definition for hemiretinal vein occlusion. Previously, physicians have treated hemiretinal vein occlusion in the same manner as $\mathrm{CRVO}^{4}$; however, with the introduction of ranibizumab, a clinical approach similar to BRVO has been adopted.

\section{Ischaemic RVO}

Ischaemic RVO has not been systematically addressed in clinical trials with ranibizumab. In the BRAVO and CRUISE studies, no patients from the BRAVO, and only two patients from the CRUISE study met the generally accepted definition for ischaemic $\mathrm{RVO}^{41} 4254$ ( $\geq 10$ disc areas of capillary non-perfusion). ${ }^{55}$ Patients with brisk afferent pupillary defect, ${ }^{56}$ a recognised indicator of ischaemia, were excluded from these studies. ${ }^{41} 42$ Because of the limited clinical experience with ranibizumab in the treatment of ischaemic RVO, the approved EU label does not recommend ranibizumab for patients presenting with irreversible ischaemic visual loss.

Physicians should use their own judgement in patients with macular ischaemia affecting the fovea as to whether any functional improvement might be achieved with ranibizumab treatment.

\section{When should treatment with ranibizumab commence?}

The correlation between duration of macular oedema and poorer visual outcomes in patients with RVO suggests that prompt initiation of treatment is beneficial. Although spontaneous resolution of macular oedema is seen in some patients, ${ }^{57}$ it is difficult to predict the prognosis for patients with BRVO in the acute phase of the disease. ${ }^{4}$ Patients with untreated, symptomatic BRVO presenting with poor VA (baseline VA ranging from 20/40 to 20/200) may experience some VA improvement over time; however, vision rarely improves beyond 20/40. ${ }^{43} 4457$

In the BRAVO and CRUISE studies, significant improvements in BCVA were observed as early as 7 days after the first ranibizumab injection. ${ }^{4142}$ Delaying ranibizumab treatment by 3 months (retinal vein occlusion) or 6 months (BRAVO and CRUISE) resulted in slower overall anatomical improvements and lower net improvements in BCVA and vision-related QoL at month $12 .{ }^{43446}$ There are different approaches to initiating treatment, ranging from immediate treatment to treatment after 1-3 months of observation so as not to treat transitory decrease of vision associated with some forms of RVO. Although administration of intravitreal ranibizumab is not without risk, these risks may be minimal compared with delayed recovery and potential permanent damage from delaying treatment. Early treatment is recommended for patients with CRVO. In cases of BRVO in which VA is marginally affected, the benefit of observation versus early treatment should be thoroughly discussed with the patient. In general, early treatment is recommended to optimise long-term VA benefits.

\section{Recommendations for the initiation of treatment}

Optical coherence tomography (OCT) permits detailed assessment and quantification of the degree and type of oedema and, as such, is considered essential for determining whether visual impairment is due to macular oedema in patients with RVO. In accordance with the approved label, ranibizumab treatment should be initiated with monthly injections and continued until maximum VA is achieved (ie, when VA is stable for three consecutive monthly assessments performed while on treatment; figure 2A). Because of the inherent variability in BCVA assessments, physicians should use their clinical judgement to determine when stable VA has been achieved.

Patients who do not experience any improvement in BCVA for the initial three monthly assessments while on treatment can be considered as non-responders to ranibizumab and continued treatment is not recommended. Fluorescein angiography may be performed during follow-up of these patients to evaluate any progression of ischaemia, but is not considered essential. OCT evaluation of these patients may also be important to guide future treatment.

When initiating treatment for RVO, physicians should be aware of systemic risk factors and refer patients to the
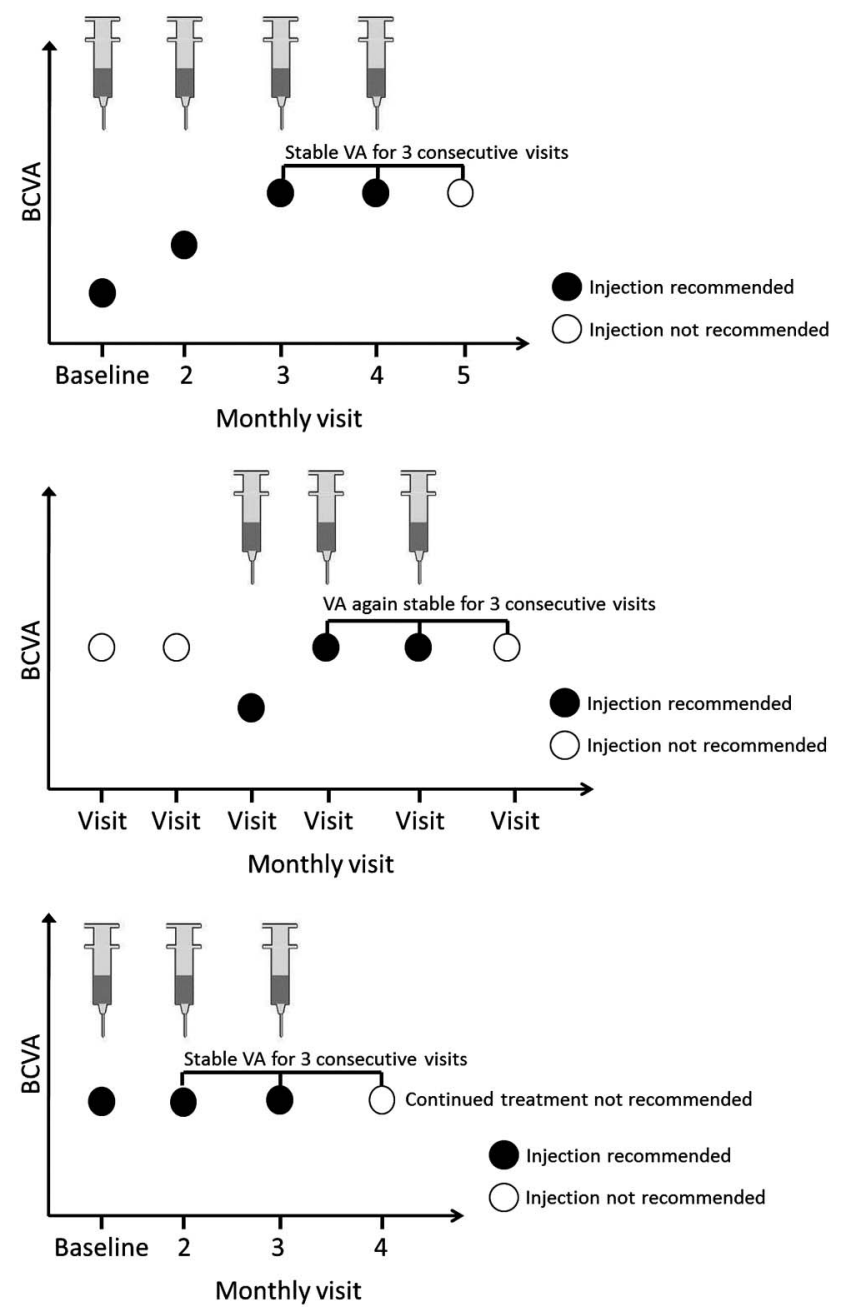

Figure 2 Timing of treatment initiation, interruption, retreatment and treatment termination with ranibizumab in retinal vein occlusion. (A) Monthly treatment is initiated and continued until maximum VA is achieved ('maximum VA' defined as: VA stable for three consecutive monthly assessments while on ranibizumab treatment). (B) Treatment is resumed when loss of VA is observed during monthly monitoring (monthly injections should be administered until VA is again stable for three consecutive monthly assessments while on ranibizumab treatment). (C) If no improvement in VA is observed over a course of three injections, continued treatment with ranibizumab is not recommended. BCVA, best-corrected visual acuity; VA, visual acuity. 
appropriate specialist if necessary (see tables S1 and S2; online supplementary material). ${ }^{16}$

\section{Follow-up examinations to determine retreatment need Best-corrected VA}

Once stable VA is achieved, treatment can be interrupted; however, monthly monitoring should continue. Monthly ranibizumab treatment is reinitiated when a loss of VA resulting from macular oedema secondary to RVO is observed (figure 2B), and this treatment is continued until stable VA is again achieved for three consecutive monthly assessments while on treatment (figure 2C). This recommendation is based on a retrospective analysis of VA response to initiation, interruption and reinitiation of ranibizumab treatment in the BRAVO and CRUISE studies. The visit at which VA had been stable for three consecutive monthly assessments while on treatment was named the 'stability visit'. Mean VA change 1 month after the VA stability visit was +0.8 letters (BRAVO) and +1.7 letters (CRUISE). The mean VA change 1 month after ranibizumab reinitiation after VA loss was +6.6 letters (BRAVO) and +9.8 letters (CRUISE).$^{58}$ Currently, the threshold at which to initiate retreatment because of VA loss has not been defined.

\section{Anatomical evaluation}

At treatment initiation, OCT evaluation should be performed to determine whether the observed loss of VA can be attributed to macular oedema. Fluorescein angiography is recommended to assess the presence and extent of ischaemia (foveal and peripheral) as well as retinal neovascularisation, unless haemorrhage has prevented sufficient visibility.

\section{Quality of life}

Formal assessments of QoL may be impractical in everyday clinical practice; however, the patient's perception of the benefits of the chosen treatment is an important factor and may be considered. At month 6, patients with BRVO treated with ranibizumab $0.5 \mathrm{mg}$ experienced a mean improvement in the NEI VFQ-25 composite score of 10.4 points, compared with 5.4 points in the sham group $(\mathrm{p}<0.005) .{ }^{41} 43$ The corresponding values for patients with CRVO were 6.2 points compared with 2.8 points, respectively $(\mathrm{p}<0.01) .{ }^{44}$ During months $6-12$, improvements in the ranibizumab $0.5 \mathrm{mg}$ groups were maintained with $\mathrm{PRN}$ ranibizumab, and VFQ-25 scores increased when patients on sham were switched to ranibizumab. ${ }^{43} 44$

\section{Additional laser treatment}

For peripheral ischaemia, most ophthalmologists consider a degree of ischaemia of 5 disc diameters in BRVO, and 10 disc diameters in CRVO as significant. There is no evidence that addition of grid macular laser panretinal photocoagulation to ranibizumab treatment provides any additional clinical benefit for patients with visual impairment due to macular oedema secondary to BRVO. In fact, in the recent RABAMES Study (Hattenbach et al, 2013 submitted), additional laser treatment was shown to have no beneficial effect.

Selective scatter photocoagulation in combination with anti-VEGF therapy is recommended by some physicians for the treatment of extensive peripheral ischaemia. Indirect evidence suggests that laser treatment of ischaemic areas can decrease the amount of VEGF within the eye and, therefore, might have a synergistic effect with the anti-VEGF therapy, decreasing the number of injections required. ${ }^{59}$ Although not proven, this approach seems logical, but randomised clinical trials are required to verify this approach. Of note, anti-VEGF therapy does not treat peripheral ischaemia and should be considered as supplemental therapy rather than replacement therapy. Laser therapy should not be performed before initiation of ranibizumab injections because this will worsen macular oedema.

\section{FUTURE CONSIDERATIONS}

These recommendations are likely to be updated as additional long-term data on the treatment of visual impairment caused by macular oedema secondary to RVO with ranibizumab become available. Endeavours to optimise therapeutic outcomes in patients with RVO while decreasing treatment burden and improving QoL are desirable, and increased clinical experience will ultimately allow physicians to make the best choices for their patients.

Acknowledgements The authors would like to acknowledge the following for their contribution to these guidelines: David Epstein (Sweden); Urban Eriksson (Sweden); Reinier Schlingemann (The Netherlands); Marta Misiuk-Hojło (Poland); Torben Lykke Sørensen (Denmark); Jana Stefanickova (Slovakia); Rufino Silva (Portugal); Rita Flores (Portugal); Jiři Řehák (Czech Republic); Laurence Postelmans (Belgium); Eleni Loukianou (Cyprus); Sebastian Wolf (Switzerland); Justus Garweg (Switzerland); Nicole Eter (Germany); Nicolas Feltgen (Germany); Stavros Dimitrakos (Greece); Valerie Krivosic (France); Catherine Creuzot-Garcher (France); Francesco Bandello (Italy); Paolo Lanzetta (Italy); Andrea Sodi (Italy); Monica Varano (Italy); Yit Yang (UK); Francisco Gómez-Ulla (Spain); Luis Arias (Spain); and Marta S Figueroa (Spain). The authors would also like to acknowledge Kate Haynes of Chameleon Communications International, who provided medical writing services with funding from Novartis Pharma AG.

Funding The expert panel meeting was sponsored by Novartis Pharma AG. As funding sponsors, they have had the opportunity to review the manuscript, but did not have authority to change any aspect of the manuscript. Funding for the expert panel meeting and medical writing services was provided by Novartis Pharma AG, Basel, Switzerland.

Competing interests $\mathrm{HG}$ received payment as a consultant to Novartis, Bayer and Allergan, and lecture honoraria from Novartis, Bayer and Heidelberg Engineering. JM has acted as a consultant/advisor to Novartis, Alcon, Allergan, Bayer, Ophthotech, Notal vision and Alimera. He has received grant support from Novartis, Bayer and Ophthotech and lecture fees from Novartis, Allergan and Ophthotech. RT has financial relationships with the following: Novartis Pharmaceuticals Corporation, Allergan, Alcon, Bausch + Lomb, Bayer HealthCare, Alimera, DORC, FCl, Pfizer, Thea and Takeda. FB has received payment as a consultant to Novartis, Bayer, Alcon, ThromboGenics, Alimera and Allergan, and lecture honoraria from Novartis and Bayer. IP has acted as a consultant/advisor to Novartis and has received lecture fees from Novartis, Allergan and Heidelberg Engineering.

Provenance and peer review Not commissioned; externally peer reviewed.

Open Access This is an Open Access article distributed in accordance with the Creative Commons Attribution Non Commercial (CC BY-NC 3.0) license, which permits others to distribute, remix, adapt, build upon this work non-commercially, and license their derivative works on different terms, provided the original work is properly cited and the use is non-commercial. See: http://creativecommons.org/ licenses/by-nc/3.0/

\section{REFERENCES}

1 Argon Laser Photocoagulation for Macular Edema in Branch Vein Occlusion. The Branch Vein Occlusion Study Group. Am J Ophthalmol 1984;98:271-82.

2 Baseline and Early Natural History Report. The Central Vein Occlusion Study. Arch Ophthalmol 1993;111:1087-95.

3 Shahid H, Hossain P, Amoaku WM. The management of retinal vein occlusion: is interventional ophthalmology the way forward? Br J Ophthalmol 2006;90:627-39.

4 Rehak M, Wiedemann P. Retinal vein thrombosis: pathogenesis and management. J Thromb Haemost 2010;8:1886-94.

5 Awdeh RM, Elsing SH, Deramo VA, et al. Vision-related quality of life in persons with unilateral branch retinal vein occlusion using the 25-item National Eye Institute Visual Function Questionnaire. Br J Ophthalmol 2010;94:319-23.

6 Deramo VA, Cox TA, Syed $A B$, et al. Vision-related quality of life in people with central retinal vein occlusion using the 25-item National Eye Institute Visual Function Questionnaire. Arch Ophthalmol 2003;121:1297-302.

7 Evaluation of Grid Pattern Photocoagulation for Macular Edema in Central Vein Occlusion. The Central Vein Occlusion Study Group M report. Ophthalmology 1995; 102:1425-33.

8 Scott IU, Ip MS, VanVeldhuisen PC, et al. A randomized trial comparing the efficacy and safety of intravitreal triamcinolone with standard care to treat vision loss 
associated with macular edema secondary to branch retinal vein occlusion: the Standard Care vs Corticosteroid for Retinal Vein Occlusion (SCORE) study report 6. Arch Ophthalmol 2009;127:1115-28

9 Ip MS, Scott IU, VanVeldhuisen PC, et al. A randomized trial comparing the efficacy and safety of intravitreal triamcinolone with observation to treat vision loss associated with macular edema secondary to central retinal vein occlusion: the Standard Care vs Corticosteroid for Retinal Vein Occlusion (SCORE) study report 5. Arch Ophthalmol 2009;127:1101-14.

10 Haller JA, Bandello F, Belfort R Jr., et al. Dexamethasone intravitreal implant in patients with macular edema related to branch or central retinal vein occlusion twelve-month study results. Ophthalmology 2011;118:2453-60.

11 Genentech. FDA Approves Lucentis ${ }^{\circledR}$ (Ranibizumab Injection) for the Treatment of Macular Edema Following Retinal Vein Occlusion. 2010. http://www.gene.com/ media/press-releases/12827/2010-06-22/fda-approves-lucentis-ranibizumab-inject (accessed 13 May 2014)

12 Novartis Europharm Limited. Lucentis ${ }^{\circledR}$ (ranibizumab) Summary of Product Characteristics. 2014. http://www.ema.europa.eu/docs/en_GB/document_library/ EPAR_-_Product_Information/human/000715/WC500043546.pdf (accessed 12 May 2014)

13 Genentech Inc. Lucentis ${ }^{\circledR}$ (ranibizumab) Prescribing Information. 2013. http://www. gene.com/gene/products/information/pdf/lucentis-prescribing.pdf (accessed 1 Feb 2013)

14 Novartis. Novartis gains new indication for Lucentis ${ }^{\circledR}$ in EU for vision loss due to Diabetic Macular Edema, a leading cause of blindness. 2011. http://www.novartis. com/newsroom/media-releases/en/2011/1477848.shtml (accessed 12 May 2014)

15 The Royal College of Ophthalmologists. Interim guidelines for management of retinal vein occlusion. London: The Royal College of Ophthalmologists, 2010. http:/l www.rcophth.ac.uk/core/core_picker/download.asp?id=728\&filetitle=Interim +Guidelines+for+Management+of+Retinal+Vein+Occlusion+2010 (accessed 12 May 2014)

16 Coscas G, Loewenstein A, Augustin A, et al. Management of retinal vein occlusion-consensus document. Ophthalmologica 2011;226:4-28.

17 Deutsche Ophthalmologische Gesellschaft. Stellungnahme der Deutschen Ophthalmologischen Gesellschaft und des Berufsverbandes der Augenärzte Deutschlands zur Therapie des Makulaödems beim retinalen Venenverschluss: Therapeutische Strategien. Ophthalmologica 2012;109:818-31.

18 Forsythe JA, Jiang BH, lyer NV, et al. Activation of vascular endothelial growth factor gene transcription by hypoxia-inducible factor 1. Mol Cell Biol 1996;16:4604-13.

19 Karia N. Retinal vein occlusion: pathophysiology and treatment options. Clin Ophthalmol 2010;4:809-16.

20 Aiello LP, Avery RL, Arrigg PG, et al. Vascular endothelial growth factor in ocular fluid of patients with diabetic retinopathy and other retinal disorders. N Engl J Med 1994;331:1480-7.

21 Noma $\mathrm{H}$, Funatsu $\mathrm{H}$, Yamasaki $\mathrm{M}$, et al. Pathogenesis of macular edema with branch retinal vein occlusion and intraocular levels of vascular endothelial growth factor and interleukin-6. Am J Ophthalmol 2005;140:256-61.

22 Noma $\mathrm{H}$, Minamoto A, Funatsu $\mathrm{H}$, et al. Intravitreal levels of vascular endothelial growth factor and interleukin- 6 are correlated with macular edema in branch retinal vein occlusion. Graefes Arch Clin Exp Ophthalmol 2006;244:309-15.

23 Noma H, Funatsu H, Yamasaki M, et al. Aqueous humour levels of cytokines are correlated to vitreous levels and severity of macular oedema in branch retinal vein occlusion. Eye (Lond) 2008;22:42-8.

24 Noma H, Funatsu H, Mimura T, et al. Vitreous levels of pigment epithelium-derived factor and vascular endothelial growth factor in macular edema with central retinal vein occlusion. Curr Eye Res 2011;36:256-63.

25 Kwong TQ, Mohamed M. Anti vascular endothelial growth factor therapies in ophthalmology: current use, controversies and the future. Br J Clin Pharmacol 2014; doi: $10.1111 /$ bcp. 12371.

26 NICE. Ranibizumab for treating choroidal neovascularisation associated with pathological myopia. 2013.

27 Bayer HealthCare. Eyelea ${ }^{\circledR}$ (aflibercept) Summary of Product Characteristics. 2014.

28 Martin DF, Maguire MG, Ying GS, et al. Ranibizumab and bevacizumab for neovascular age-related macular degeneration. N Engl J Med 2011;364:1897-908.

29 Chakravarthy U, Harding SP, Rogers CA, et al. Ranibizumab versus bevacizumab to treat neovascular age-related macular degeneration: one-year findings from the IVAN randomized trial. Ophthalmology 2012;119:1399-411.

30 Krebs I, Schmetterer L, Boltz A, et al. A randomised double-masked trial comparing the visual outcome after treatment with ranibizumab or bevacizumab in patients with neovascular age-related macular degeneration. $\mathrm{Br} J$ Ophthalmol 2013;97:266-71.

31 Kodjikian L, Souied EH, Mimoun G, et al. Ranibizumab versus bevacizumab for neovascular age-related macular degeneration: results from the GEFAL noninferiority randomized trial. Ophthalmology 2013;120:2300-9.

32 Beutel J, Ziemssen $F$, Luke $M$, et al. Intravitreal bevacizumab treatment of macular edema in central retinal vein occlusion: one-year results. Int Ophthalmol 2010;30:15-22.
33 Ferrara DC, Koizumi H, Spaide RF. Early bevacizumab treatment of central retinal vein occlusion. Am J Ophthalmol 2007;144:864-71.

34 Figueroa MS, Contreras I, Noval S, et al. Results of bevacizumab as the primary treatment for retinal vein occlusions. Br J Ophthalmol 2010;94:1052-6.

35 Hoeh AE, Ach T, Schaal KB, et al. Long-term follow-up of OCT-guided bevacizumab treatment of macular edema due to retinal vein occlusion. Graefes Arch Clin Exp Ophthalmol 2009;247:1635-41.

36 Prager F, Michels S, Kriechbaum K, et al. Intravitreal bevacizumab (Avastin) for macular oedema secondary to retinal vein occlusion: 12-month results of a prospective clinical trial. Br J Ophthalmol 2009;93:452-6.

37 Yuan A, Ahmad BU, Xu D, et al. Comparison of intravitreal ranibizumab and bevacizumab for the treatment of macular edema secondary to retinal vein occlusion. Int J Ophthalmol 2014;7:86-91.

38 ClinicalTrials.gov. NCT01969708. 2013.

39 Wroblewski JJ, Wells JA III, Adamis AP, et al. Pegaptanib sodium for macular edema secondary to central retinal vein occlusion. Arch Ophthalmol 2009;127:374-80.

40 Heier JS, Clark WL, Boyer DS, et al. Intravitreal aflibercept injection for macular edema due to central retinal vein occlusion: two-year results from the COPERNICUS study. Ophthalmology 2014; doi: 10.1016/j.ophtha.2014.01.027.

41 Campochiaro PA, Heier JS, Feiner L, et al. Ranibizumab for macular edema following branch retinal vein occlusion: six-month primary end point results of a phase III study. Ophthalmology 2010;117:1102-12.

42 Brown DM, Campochiaro PA, Singh RP, et al. Ranibizumab for macular edema following central retinal vein occlusion: six-month primary end point results of a phase III study. Ophthalmology 2010;117:1124-33.

43 Brown DM, Campochiaro PA, Bhisitkul RB, et al. Sustained benefits from ranibizumab for macular edema following branch retinal vein occlusion: 12-month outcomes of a phase III study. Ophthalmology 2011;118:1594-602.

44 Campochiaro PA, Brown DM, Awh CC, et al. Sustained benefits from ranibizumab for macular edema following central retinal vein occlusion: twelve-month outcomes of a phase III study. Ophthalmology 2011;118:2041-9.

45 Heier JS, Campochiaro PA, Yau L, et al. Ranibizumab for macular edema due to retinal vein occlusions: long-term follow-up in the HORIZON trial. Ophthalmology 2012;119:802-9.

46 Kinge $B$, Stordahl PB, Forsaa $V$, et al. Efficacy of ranibizumab in patients with macular edema secondary to central retinal vein occlusion: results from the sham-controlled ROCC study. Am J Ophthalmol 2010;150:310-4.

47 Risard SM, Pieramici DJ, Rabena MD, et al. Intravitreal ranibizumab for macular edema secondary to central retinal vein occlusion. Retina 2011;31: 1060-7.

48 Campochiaro PA, Hafiz G, Channa R, et al. Antagonism of vascular endothelial growth factor for macular edema caused by retinal vein occlusions: two-year outcomes. Ophthalmology 2010;117:2387-94.

49 Spaide RF, Chang LK, Klancnik JM, et al. Prospective study of intravitreal ranibizumab as a treatment for decreased visual acuity secondary to central retinal vein occlusion. Am J Ophthalmol 2009;147:298-306.

50 Campochiaro PA, Hafiz G, Shah SM, et al. Ranibizumab for macular edema due to retinal vein occlusions: implication of VEGF as a critical stimulator. Mol Ther 2008;16:791-9.

51 Alfaro DV III, Jablon EP, Kerrison JB, et al. Ranibizumab for the treatment of branch retinal vein occlusion-associated cystoid macular edema [abstract]. Invest Ophthalmol Vis Sci 2008;49:2699.

52 Pieramici DJ, Rabena M, Castellarin AA, et al. Ranibizumab for the treatment of macular edema associated with perfused central retinal vein occlusions. Ophthalmology 2008;115:e47-54

53 Wykrota H, Trzciakowski K, Gierek-Lapinska A. Ranibizumab treatment of macular edema secondary to retinal vein occlusion [abstract]. 8th EURETINA Congress, 2225 May 2008

54 Campochiaro PA, Johnson MW, Arevalo JF, et al. Vascular endothelial growth factor promotes progressive retinal nonperfusion in patients with retinal vein occlusion. Ophthalmology 2013;120:795-802.

55 Arvas S, Ocakoglu 0, Ozkan S. The capillary blood flow in ischaemic type central retinal vein occlusion: the effect of laser photocoagulation. Acta Ophthalmol Scand 2002;80:490-4.

56 Servais GE, Thompson HS, Hayreh SS. Relative afferent pupillary defect in central retinal vein occlusion. Ophthalmology 1986;93:301-3.

57 Rogers SL, McIntosh RL, Lim L, et al. Natural history of branch retinal vein occlusion: an evidence-based systematic review. Ophthalmology 2010;117:1094-101.

58 Pearce I, Gerding H, Mitchell P, et al. Evaluation of individual patient ranibizumab treatment based on a visual acuity stability concept in retinal vein occlusion patients [abstract]. American Academy of Ophthalmology 2011:P0547.

59 Shah AM, Bressler NM, Jampol LM. Does laser still have a role in the management of retinal vascular and neovascular diseases? Am J Ophthalmol 2011;152:332-9. 